\title{
Bathyal species in Rissoidae (Gastropoda) from Azorean seamounts
}

\author{
Leon Hoffman* \& André Freiwald
}

Marine Research Department, Senckenberg am Meer, Südstrand 40, Wilhelmshaven, Germany

*Corresponding author, e-mail: leon.hoffman@senckenberg.de

\begin{abstract}
Three new species in the family Rissoidae (Gastropoda) have been found in bioclastic sediment samples taken on the bathyal slopes of two Azorean seamount areas during the cruise M151 Athena by R/V Meteor: Alvania templadoi n. sp., Crisilla avilai n. sp. and Crisilla herosae n. $\mathrm{sp}$. A review of endemicity in bathyal rissoids is presented; the large majority ( $81 \%$ ) of the rissoids are endemic to the Azorean region. The distribution of species is frequently ( $20 \%$ of rissoids) limited to a single seamount, a seamount cluster or to the full Azorean seamounts and islands province. The degree of endemicity is comparable between the northern and southern Azorean seamount areas and between shallow-water species and bathyal species in the northern area. Endemic species and genera evolved after the formation of the islands and seamounts during the Neogene following an early population by species from eastern Atlantic genera.
\end{abstract}

KEY WORDS Mollusca; Alvania; Crisilla; Azores; Atlantic Ocean.

Received 02.06.2021; accepted 14.09.2021; published online 04.10.2021

\section{INTRODUCTION}

Species in the family Rissoidae Gray, 1847 are grazing and deposit-feeding gastropods living on a large variety of sea bottoms, from the intertidal zone to abyssal depths in all oceans of the world. Fossil rissoids are known since the Permian (Sepkoski, 2002). The family Rissoidae contains a large number of Recent species in 48 genera (WoRMS, 2020). This paper discusses new and poorly-known bathyal rissoids from Azorean seamounts in the northern Atlantic Ocean.

Recent papers discussed the occurrence of rissoids from the Azores. Gofas (1990) reviewed 11 littoral rissoids from São Miguel Island of which 8 were considered endemic; three new species were described. Bouchet \& Warén (1993) described the bathyal and abyssal mesogastropods of the NE Atlantic including Rissoidae; they reported 11 bathyal rissoids from the Azores of which three new species were described. Only three Azorean species were reported to have a North Atlantic distribution (Bouchet \& Warén, 1993). Hoenselaar \& Goud (1998) discussed the Rissoidae collected during the CANCAP expeditions; two endemic species in the genus Alvania Risso, 1826 were described from the Azores. Gofas (2007) reported on 24 rissoid species that were sampled during the Seamount 2 cruise in an area spanned by the Atlantis Seamount, the Tyro Seamount and the Great Meteor Seamount. 22 species (92\%) are most likely endemic to the southern Azorean seamount area and only two species have a wider NE Atlantic distribution; 18 species were newly described (Gofas, 2007). Ávila et al. (2009, and references therein) provide a comprehensive dis- 
cussion on the origin of the marine malacofauna from the Azores. Ávila et al. (2012) provided an analysis of the distributions of Rissoidae in the Atlantic Ocean; a strong generic association with $\mathrm{NE}$ Atlantic rissoids was proven. Cordeiro \& Ávila (2015) gave a checklist with 39 rissoid species from the area around the Azorean islands of which 15 species occur in deep water. Among these 15 deep-water species, 9 species $(60 \%)$ are considered endemic to the bathyal slopes and plateaus near the Azorean islands.

The formation of the Azorean islands and seamounts were triggered by a volcanic hotspot during the Late Miocene ( $8 \mathrm{Ma}$ ) and continued for the most recent islands and seamounts into the Late Pleistocene (0.25 Ma) (Madeira, 1986; Serralheiro \& Madeira, 1990; Serralheiro, 2003). The group of southern Azorean seamounts (Atlantis, Plato, Tyro, Irving, Hyères, Great Meteor and Little Meteor) was also formed by a volcanic hotspot starting in the Middle Paleogene (about $40 \mathrm{Ma}$ ) at the Plato seamount until the Middle Miocene (about $11 \mathrm{Ma}$ ) at the Meteor Seamount. The prevailing sea current around the Azores during the Late Miocene was weak prior to the closure of the Panama Isthmus. This closure caused major changes in ocean circulation starting at about 4.6 Ma in the Early Pliocene (Coates \& Obando, 1996; Haug \& Tiedemann, 1998) when the Gulf Stream developed with a strong NE current direction. Driscoll \& Haug (1998) suggested a circulating current pattern in which the Gulf Stream initially passed the west of the Azores with a return current passing East of the Azores in southward direction. This current pattern slowed down and was pushed southwards during Late Pliocene and Pleistocene glaciations. The Azorean islands and seamounts must have been populated shortly after their formation. The Gulf Stream could have enhanced population from the western Atlantic. However, Pleistocene and Recent rissoid genera are similar to those of the eastern Atlantic (Ávila et al., 2009). The oceanographical isolation of the Azorean seamounts must have contributed to the large endemicity (Gofas 1990, 2007; Bouchet \& Warén, 1993; Ávila et al., 2009, 2012; Cordeiro \& Ávila, 2015).

ABBREVIATIONS. Morphology: $\mathrm{H}=$ height; $\mathrm{Ha}=$ height of aperture; $\mathrm{Hp}=$ height of protoconch; $\mathrm{W}=$ width; $\mathrm{Wp}=$ width of protoconch. Institutions: MNHN = Muséum National de Histoire Naturelle,
Paris (France); SaM = Senckenberg am Meer, Wilhemshaven (Germany); SMF = Senckenberg Museum, Frankfurt am Main (Germany).

\section{MATERIAL AND METHODS}

\section{Study area}

This study used benthic samples from two seamounts south of the Azores: Mar da Prata / José Gaspar Seamount south of São Miguel, and Açor Bank SW of Fayal. The location data from the M151 cruise has been reported in Frank (2018). Coordinates have been converted to a digital format to facilitate their use in geographic interface systems and in general analyses.

\section{Sampling and material handling}

Refer to Hoffman \& Freiwald (2020) for a description of the sampling procedure. Selected shells were imaged using a Keyence confocal microscope and a Vega3-Tescan scanning electron microscope (SEM) at SaM. The SEM samples were gold-coated to improve image quality. SEM imaging has been done by using secondary- as well as back-scatter electrons; shell measurements have been done using the SEM analysis software.

\section{Distribution of species}

The sampling methodology provides an inhomogeneous distribution of species on the sea floor. Consequently, the presence / absence as well as abundance of species in our samples are a poor representation of their actual distribution. We have chosen to represent the distribution by the minimum and maximum latitude and longitude observed. A maximum distribution distance is given by:

$$
\mathrm{D}=\sqrt{ }\left(\Delta \mathrm{Lat}^{2}+\Delta \mathrm{Lon}^{2}\right) \quad[\mathrm{km}]
$$

Where $\Delta$ Lat is the NS great arc distance between the minimum and maximum latitude observed and $\Delta$ Lon is the EW great arc distance between the minimum and maximum longitude observed at the mean latitude. This study used the locations published by Bouchet \& Warén (1993), Gofas (2007) and the large bathyal species data set 
at SaM, which include the finds from cruise M151 as well as from many other cruises by German cruises in the northern Atlantic.

\section{Storage of type material}

Holotypes are deposited in Muséum national de Histoire naturelle (MNHN), Paris (France); paratypes are retained in MNHN, Senckenberg Museum, Frankfurt am Main (SMF) (Germany) and in the reference collection at Senckenberg am Meer (SaM) (Germany). Other reference specimens are stored in the collection at SaM.

\section{RESULTS}

\section{Systematics}

Classis GASTROPODA Cuvier, 1795

Subclassis CAENOGASTROPODA Cox, 1960

Ordo LITTORINIMORPHA Golikov et Starobogatov, 1975

Superfamilia RISSOOIDEA Gray, 1847

Familia RISSOIDAE Gray, 1847

Genus Alvania Risso, 1826

TYPE SPECIES. Alvania europea Risso, 1826 accepted as Alvania cimex (Linnaeus, 1758), type by subsequent designation.

Alvania templadoi n. sp. (Figs. 1-8)

http://zoobank.org/urn:lsid:zoobank.org:act:EDFB B47F-17A1-4593-8E4B-8875CF792A24

Type Locality. Azores, Mar da Prata, 37.673 ${ }^{\circ} \mathrm{N}, 25.925{ }^{\circ} \mathrm{W}, 595 \mathrm{~m}$.

Type material. Holotype: Azores, Mar da Prata, 1 shell, $37.673{ }^{\circ} \mathrm{N}, 25.925^{\circ} \mathrm{W}, 595 \mathrm{~m}$, 8.X.2018, M151-23111, grab, MNHN-IM-200029912. Paratype 1: 1 shell, same data as holotype, MNHN-IM-2000-29913. Paratypes 2: 3 shells, $37.669^{\circ} \mathrm{N}, 25.926^{\circ} \mathrm{W}, 834 \mathrm{~m}, 8 . X .2018$, M15123109, grab, MNHN-IM-2000-29914. Paratypes 3: 7 shells, same data as paratypes 2, SMF 385964. Paratype 4: 1 shell, $37.669^{\circ} \mathrm{N}, 25.906^{\circ} \mathrm{W}, 406 \mathrm{~m}$, 8.X.2018, M151-23114, grab, SaM 86445.

DESCRIPTION OF THE HOLOTYPE (Figs. 1-4, empty shell). Strong small shell with a raised spire, raised apex and rounded whorls with coarse reticulate sculpture; aperture round with thickened lip; suture shallow, impressed. Height $2.14 \mathrm{~mm}$, width 1.32 $\mathrm{mm}$, height of aperture $0.78 \mathrm{~mm}$ (36\% of total height), apical angle $46^{\circ}$; colour opaque white.

Protoconch (Figs. 2, 3): 13/4 raised whorl, rounded nucleus of $1 / 2$ whorl and $1 \frac{1}{4}$ whorl with a keeled shoulder and vertically flattened whorl face at the periphery and second keel above lower suture. Sculpture: inconspicuous spiral cordlets with inconspicuous branched spiral segments; sharp flexuous rim terminating the protoconch; transition to teleoconch clear by change in sculpture. Diameter $0.38 \mathrm{~mm}$.

Teleoconch (Fig. 1 of holotype; Figs. 5-8 of paratypes): $3 \frac{1}{2}$ regular whorls with angular outline and orthogonal reticulate sculpture of sharp and straight vertical ribs overlying sharp spiral cords; pointed at crossings; about seven ribs per whorl, concave between crossings with spirals; four spirals on body whorl, concave between crossings with ribs. Strong growth lines at ribs with numerous fine growth lines between ribs. Not umbilicate; a smooth spiral cord, possibly an umbilical chink, is partly covered by columellar callus; straight thickened rim near the aperture (Figs. 6, 7).

Aperture (Fig. 5): oval; nearly circular outer lip, fine rounded margin protruding from thick external rim, rounded at union with penultimate whorl, straightened on parietal area with thin callus. Columella straightened with sharp protruding lip, rounded towards parietal area. Callus moderately thick; inside aperture smooth.

VARIABILITY. Little morphological variation observed; columella is straight in holotype and rounded in paratypes. Height up to $2.2 \mathrm{~mm}$; width up to $1.4 \mathrm{~mm}$.

Distribution. Azores, off Sao Miguel, Mar da Prata, 406-834 m.

Etymology. The species honours José Templado for his numerous suggestions that improved the study reports on the molluscan species from the South Azorean Seamount Chain.

REMARKS. Alvania templadoi n. sp. is similar to Alvania zetlandica (Montagu, 1815), a NE Atlantic species with a planktonic multispiral larval development and finely sculptured protoconch, five spiral cords, fine spiral micro-sculpture and oblique opisthocline ribs and lip whereas A. templadoi lacks the fine protoconch and teleoconch sculpture and 
has four spiral cords and orthocline ribs and lip. The sympatric Alvania platycephala Dautzenberg \& Fischer, 1896 is also similar but it has strong spiral cords on the protoconch, five spiral cords on the teleoconch and weak labial teeth (Bouchet \& Warén, 1993; de Frias Martins et al., 2009; this study, Figs 30-32). Gofas (2007) described various similar species from the southern Azorean seamounts. Alvania micropilosa Gofas, 2007 and Alvania microtuberculata Gofas, 2007 have a rounded protoconch with spiral lines and have more spiral cords. Alvania elenae Gofas, 2007 and Alvania suroiti Gofas, 2007 have a similar sculpture but their protoconchs are rounded with spiral lines.

Similar shelfal and littoral species from the Azores (de Frias Martins et al., 2009) have a protoconch with a stronger sculpture and lack the characteristic keel of $A$. templadoi n. sp. Alvania sleursi (Amati, 1987) and Alvania cancellata (da Costa, 1778) have a coarser sculpture and stronger shell.

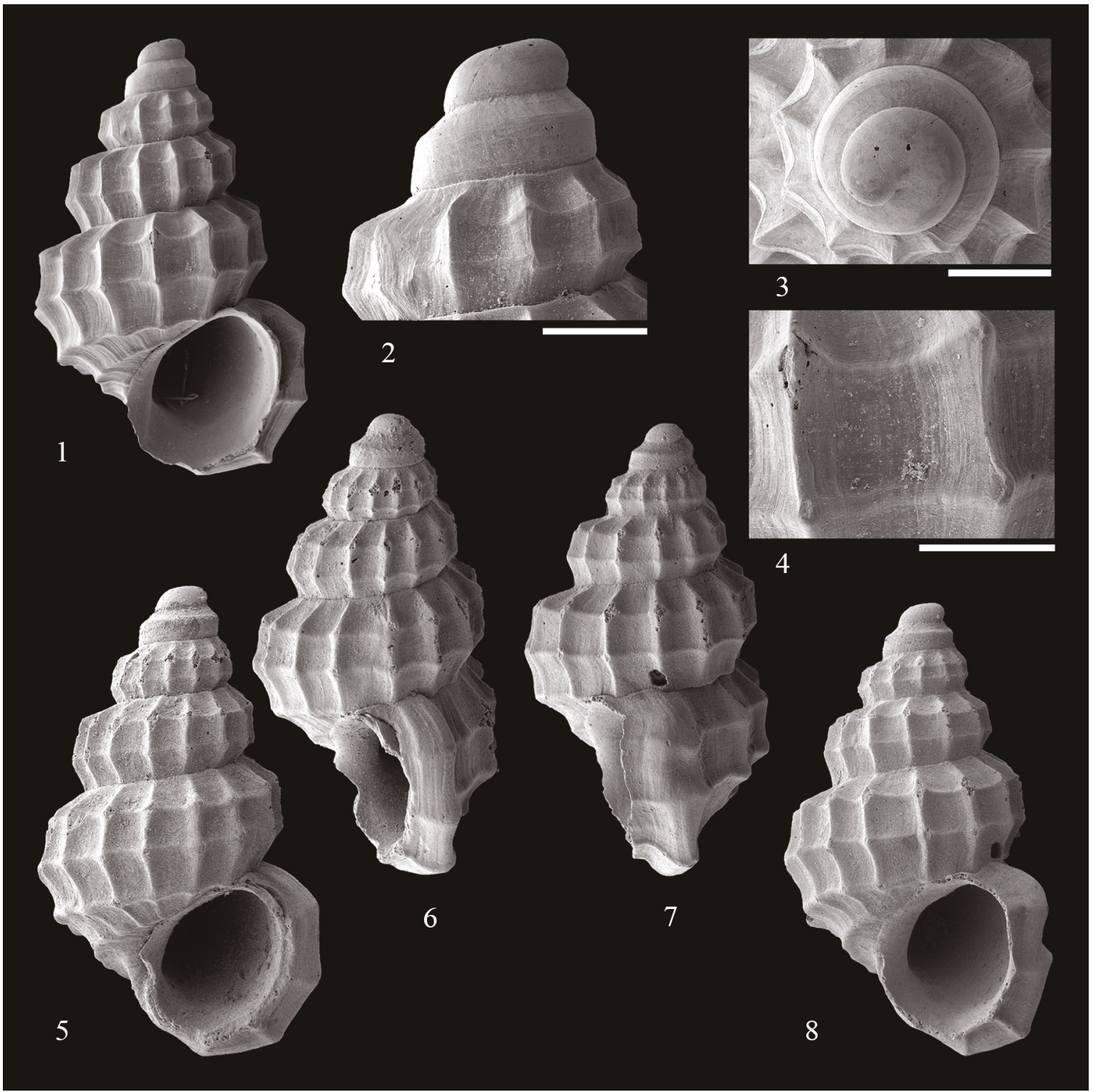

Figures 1-8. Alvania templadoi n. sp., Azores, Mar da Prata. Figs. 1-4. Holotype, M151-23111, H 2.14 mm, W 1.32 mm, Ha $0.78 \mathrm{~mm}$, protoconch Wp $0.38 \mathrm{~mm}$. Figs. 5-8. paratypes, M151-23109. Figs. 5, 6. H $2.17 \mathrm{~mm}$, W $1.28 \mathrm{~mm}, \mathrm{Ha} 0.72$ mm. Figs. 7, 8. Same location, H $2.19 \mathrm{~mm}$, W $1.22 \mathrm{~mm}$, Ha $0.75 \mathrm{~mm}$. Scale bar $0.2 \mathrm{~mm}$. 
Alvania cimicoides (Forbes, 1844) has more spiral cords on the base of the body whorl and its inner lip shows weak labial teeth.

Empty shells of Alvania templadoi n. sp. have been found in bioclastic sand with remains of scleractinians and foraminiferans.

\section{Crisilla herosae n. sp. (Figs. 9-14)}

http://zoobank.org/urn:lsid:zoobank.org:act:697 799D9-62D7-47CF-8C37-F644B5BF82B2
TyPe LoCAlity. Azores, José Gaspar Seamount, $37.674^{\circ} \mathrm{N}, 25.717^{\circ} \mathrm{W}, 311-337 \mathrm{~m}$.

TYPe Material. Holotype: Azores, José Gaspar Seamount, 1 shell, $37.674^{\circ} \mathrm{N}, 25.717^{\circ} \mathrm{W}, 337 \mathrm{~m}$, 6.X.2018, M151-23105, grab, MNHN-IM-200029915. Paratypes 1: 2 shells, same data as holotype, MNHN-IM-2000-29916. Paratypes 2, 34 shells, same data as holotype, SMF 385965. Paratypes 3: 15 shells, $37.675^{\circ} \mathrm{N}, 25.717^{\circ} \mathrm{W}, 311 \mathrm{~m}, 16 . X .2018$, M151-23161, grab, SaM 85107.

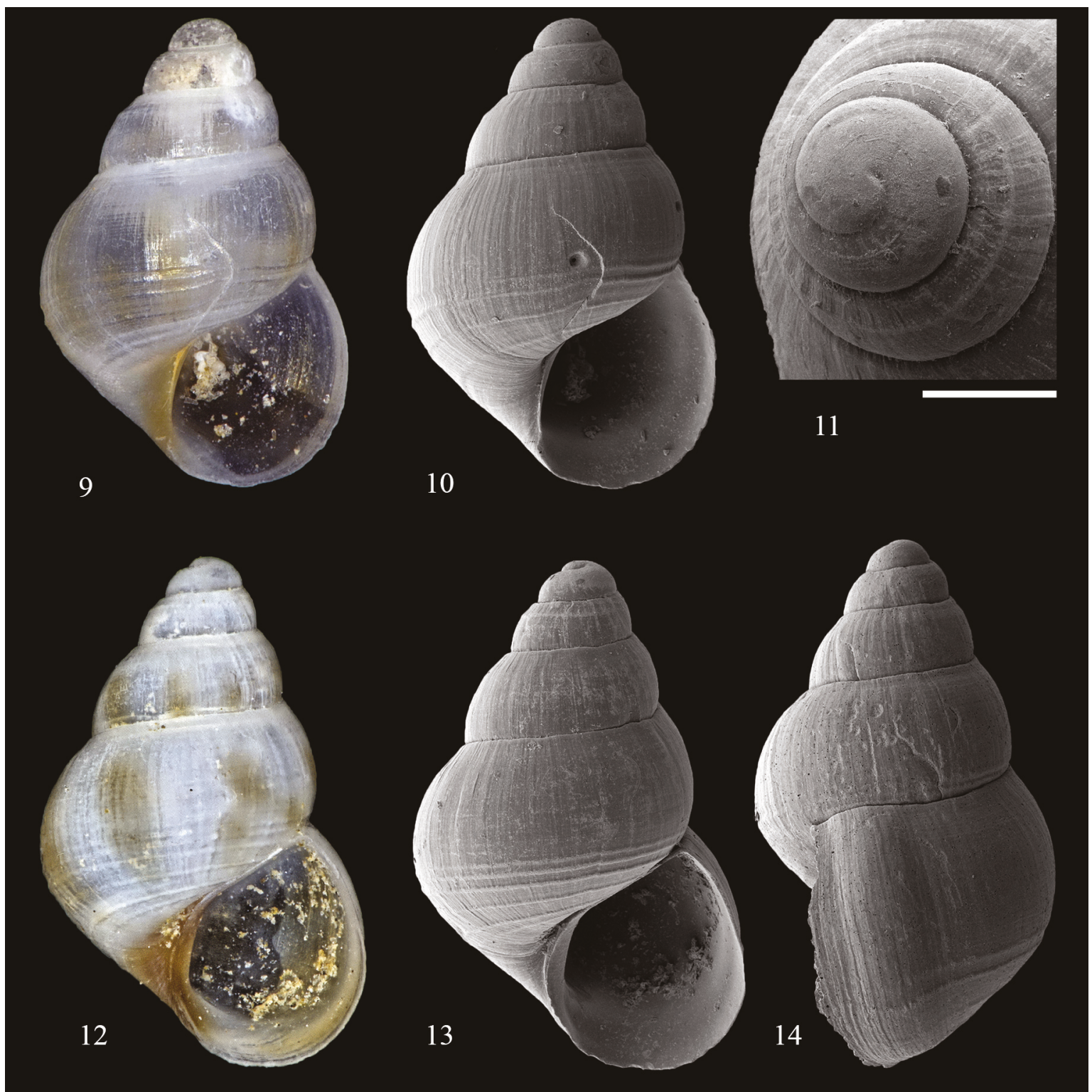

Figures 9-14. Crisilla herosae n. sp., Azores, José Gaspar Seamount, M151-23105. Figs. 9-11. Paratype, H 1.61 mm, W $1.05 \mathrm{~mm}$, Ha $0.75 \mathrm{~mm}$, protoconch Wp $0.39 \mathrm{~mm}$. Figs. 12, 13. Holotype, H $1.87 \mathrm{~mm}, \mathrm{~W} 1.21 \mathrm{~mm}$, Ha 0.79 mm. Fig. 14. Paratype, H $1.95 \mathrm{~mm}$, Ha $0.87 \mathrm{~mm}$, Wp $0.39 \mathrm{~mm}$. Scale bar $0.2 \mathrm{~mm}$. 
DesCRIPTION OF THE HOLOTYPE (Figs. 12, 13, empty shell). Fragile small shell with raised spire, rounded apex and rounded whorls with smooth whorl face and spiral cords below level of suture; aperture pyriform with thickened lip; suture shallow, impressed. Height $1.87 \mathrm{~mm}$, width $1.21 \mathrm{~mm}$, height of aperture $0.79 \mathrm{~mm}$ ( $42 \%$ of total height), apical angle $48^{\circ}$; colour translucent white with 8 10 broad brown flames on periphery; columella and adjacent base whorl surface brown.

Protoconch (Fig. 11 of paratype): $11 / 2$ raised rounded whorl. Sculpture irregular spiral cordlets; inconspicuous rim terminating the protoconch; transition to teleoconch clear by change in sculpture. Diameter $0.39 \mathrm{~mm}$.

Teleoconch (Fig. 12): three regular convexly rounded whorls with smooth upper whorl face with about seven smooth spiral cords of various strength below the level of the suture; some spiral cords are marked by white lines in the translucent shell; concave surface between two upper cords. Inconspicuous spiral rib below upper suture on first two whorls (Fig. 11). Numerous prosocline straight growth lines of variable strength at about $10^{\circ}$ with spire axis. Not umbilicate. Straight thickened rim near the aperture (Fig. 14).

Aperture (Figs. 12, 13): oval, pointed $\left(99^{\circ}\right)$ at union with penultimate whorl; oval outer lip, fine sharp bevelled margin protruding from thick external rim, concave on parietal area with thin reclining callus. Columella curved with sharp lip, rounded towards parietal area. Callus moderately thick; inside aperture smooth.

VARIABILITY. Little morphological variation observed; the number and strength of the brown flames on the whorl face vary. Height up to $2.0 \mathrm{~mm}$; width up to $1.3 \mathrm{~mm}$.

Distribution. Azores, José Gaspar Seamount, 311-377 m.

Etymology. the name herosae is dedicated to Virginie Heros for her efficient and continuous guidance during our studies of Azorean malacofauna in association with the collection at the MNHN.

Remarks. Crisilla herosae n. sp. is similar to Crisilla quisquiliarum (Watson, 1886), originally reported from a single shell off Fayal in 450-500 fathoms. The worn shell of the holotype of Crisilla quisquiliarum has been imaged by Gofas (1990: fig. 28); it has a more raised teleoconch and a brown apex where our new species is more blunt with a white apex. The littoral Crisilla postrema (Gofas, 1990) is more raised with more elongated whorls (Gofas, 1990: figs. 24, 25) with a different colour pattern, weaker spiral cordlets and it lacks a thickened aperture. Crisilla innominata (Watson, 1897) is described from Madeira is similar but it has a spiral sculpture high on the whorl face. Crisilla depicta (Manzoni, 1868) has a heavier teleoconch and a granulated protoconch. Crisilla iunioniae Palazzi, 1988 has a different colour pattern with several spiral sequences of brown blotches and it has an oblique white columella.

Empty shells of Crisilla herosae n. sp. have been found in bioclastic sand with remains of scleractinians and foraminiferans.

Crisilla avilai $\mathrm{n}$. sp. (Figs. 15-24)

http://zoobank.org/urn:lsid:zoobank.org:act:CEB5 CB85-5965-4858-832C-E6B7851A88BF

Type Locality. Azores, Mar da Prata, 37.673 ${ }^{\circ} \mathrm{N}, 25.925^{\circ} \mathrm{W}, 595 \mathrm{~m}$.

TYPE Material. Holotype: Azores, Mar da Prata, 1 shell, $37.673{ }^{\circ} \mathrm{N}, 25.925^{\circ} \mathrm{W}, 595 \mathrm{~m}, 8 . X .2018$, M151-23111, grab, MNHN-IM-2000-29917. Paratypes 1: 3 shells, same data as holotype, MNHN-IM-2000-29918. Paratypes 2: about 500 shells, same data as holotype, MNHN-IM-200029919. Paratypes 3: about 500 shells, same data as holotype, SMF 385966. Paratypes 4: about 75 shells, same data as holotype, SaM 86447. Paratypes 5: 40 shells, $37.669^{\circ} \mathrm{N}, 25.926^{\circ} \mathrm{W}, 834 \mathrm{~m}, 8 . X .2018$, M151-23109, grab, SaM 86449. Paratype 6: 1 shell, $37.669^{\circ} \mathrm{N}, 25.906{ }^{\circ} \mathrm{W}, 406$ m, 8.X.2018, M15123114, grab, SaM 86451. Paratypes 7: 2 shells, Açor Bank. $38.359^{\circ} \mathrm{N}, 29.051^{\circ} \mathrm{W}, 648 \mathrm{~m}, 13 . X .2018$, M151-23135, grab, SaM 86448.

DESCRIPTION OF THE HOLOTYPE (Figs. 15-17, empty shell). Moderately fragile small shell with raised spire, rounded apex and rounded whorls with glossy whorl face and spiral cords below the level of the suture; aperture angular with thickened lip; suture shallow, impressed. Height $1.92 \mathrm{~mm}$, width $1.27 \mathrm{~mm}$, height of aperture $0.82 \mathrm{~mm} \mathrm{(43 \%}$ of total height), apical angle $54^{\circ}$; colour translucent white with broad brown band below the periphery. 


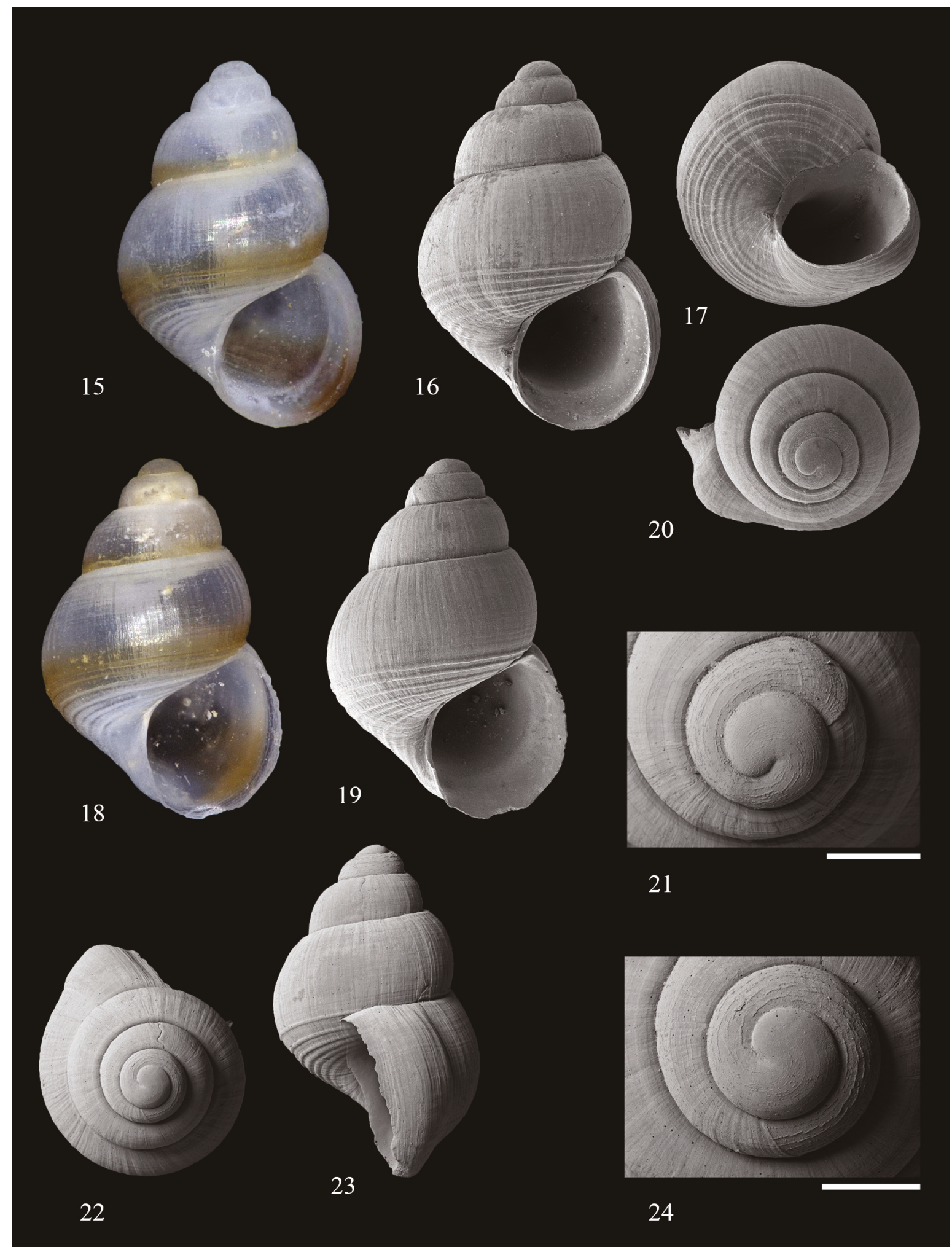

Figures 15-24. Crisilla avilai n. sp., Azores, Mar da Prata, M151-23111. Figs. 15-17. Holotype, H 1.92 mm, W 1.27 mm, Ha 0.82 mm. Figs. 18-21. Paratype, H 1.75 mm, W 1.13 mm, Ha 0.78 mm, Wp 0.39 mm. Figs. 22-24. Paratype, H 1.74 mm, W 1.28 mm, Ha $0.81 \mathrm{~mm}, \mathrm{Wp} 0.39 \mathrm{~mm}$. 
Protoconch (Figs. 21, 24 of paratypes): 1 1 1/4 raised rounded whorl, nucleus smooth with fine spiral line segments, last $3 / 4$ whorl with stronger irregular spiral cordlets; rim terminating the protoconch; transition to teleoconch clear by change in sculpture. Diameter $0.39 \mathrm{~mm}$.

Teleoconch (Figs. 15-17): 21/2 convexly rounded whorls with glossy upper whorl face with inconspicuous spiral grooves and 7-8 smooth spiral cords of equal strength below the level of the suture; most spiral cords are marked by white lines in the translucent shell. Numerous slightly prosocline straight growth lines of variable strength at about $5^{\circ}$ with spire axis. Suture descending at aperture (Fig. 23). Not umbilicate. Straight thickened rim near the aperture (Figs. 20, 22,23 ).

Aperture (Figs. 15-17): oval, bluntly pointed $\left(103^{\circ}\right)$ at union with penultimate whorl; oval outer and columellar lip, fine sharp bevelled margin protruding from thick external rim, straightened on parietal area with very thin callus. Columella curved with thin sharp lip. Callus moderately thick; inside aperture smooth.

VARIABILITY. Little morphological variation observed. Height up to $2.0 \mathrm{~mm}$; width up to 1.3 $\mathrm{mm}$.

Distribution. Azores, Mar da Prata, off São Miguel and Açor Bank off Fayal, 406-834 m.

Etymology. The name avilai is dedicated to Sérgio Ávila for his large contribution to the knowledge on the origin of the Azorean malacofauna.

Remarks. Crisilla avilai n. sp. is similar to $C$. quisquiliarum (Watson, 1886); this taxon has a more raised teleoconch with more flattened whorls and the colour pattern is different. Crisilla picta (Jeffreys, 1867) also has a banded colour pattern but is has three broad bands and its outline is more flattened with weak spiral lines. Crisilla herosae n. sp. has a more conical outline with more flattened whorls and a different colour pattern. For differences with other northeastern Atlantic species refer to the remarks under Crisilla herosae n. $\mathrm{sp}$.

Empty shells of Crisilla avilai $\mathrm{n}$. sp. have been found in bioclastic sand with remains of scleractinians and foraminiferans.

\section{DISCUSSION}

\section{Notes on bathyal Rissoidae from the north- ern Azorean seamounts}

Alvania adiaphoros Bouchet et Warén, 1993 (Figs. 25, 26) is common on all Azorean seamounts in 274-952 m (Bouchet \& Warén, 1993; Gofas, 2007; this study). In our study, it was found on the José Gaspar Seamount (M151-23105) and Mar da Prata off Sao Miguel (M151-23109, 23111, 23112, 23114, 23168), the Albatroz Seamount off Terceira (M151-23126) and the Açor Bank off Fayal (M151-23135, 23139).

Alvania adinogramma Bouchet et Warén, 1993 was known off Portugal and on the Lusitanian Seamounts in 255-1050 m (Bouchet \& Warén, 1993). It can be identified by its teleoconch sculpture and spirally aligned beads on the protoconch. In our study, Alvania cf. adinogramma Bouchet et Warén, 1993 was found on the Great Meteor Seamount (M151-23425 ROV-1, 6 and 9; Figs 27, 28) and on the Little Meteor Seamount, 23438 in 464-948 m. We are uncertain about its identification as the beads on the protoconch are present in narrow lines with fewer beads in between the lines. A similar species is Alvania tarsodes (Watson, 1886), which has a protoconch sculpture with densely dispersed beads (Bouchet \& Warén, 1993; Fig. 36).

Alvania cimicoides (Forbes, 1844) is a common NE Atlantic and Mediterranean bathyal species. It was also found on the José Gaspar Seamount (M151-23105, 23131, 23161) and Mar da Prata off São Miguel (M151-23109, 23111, 23112, 23114) and on the Açor Bank off Fayal (M151-23139).

Alvania lamellata Dautzenberg, 1889 is found on the northern Azorean seamounts in 293-1287 m. Bouchet \& Warén (1993) only referred to the type material but it proved to be quite common in our study. It was found on the José Gaspar Seamount (M151-23105, 23131) and Mar da Prata off Sao Miguel (M151-23109, 23111, 23114), the Albatroz Seamount off Terceira (M151-23128) and the Açor Bank off Fayal (M151-23135, 23139; Figs. 29, 30).

Alvania nonsculpta Hoenselaar et Goud, 1998 was described from off Flores and was also reported off Fayal in 165-200 m (Hoenselaar \& Goud, 


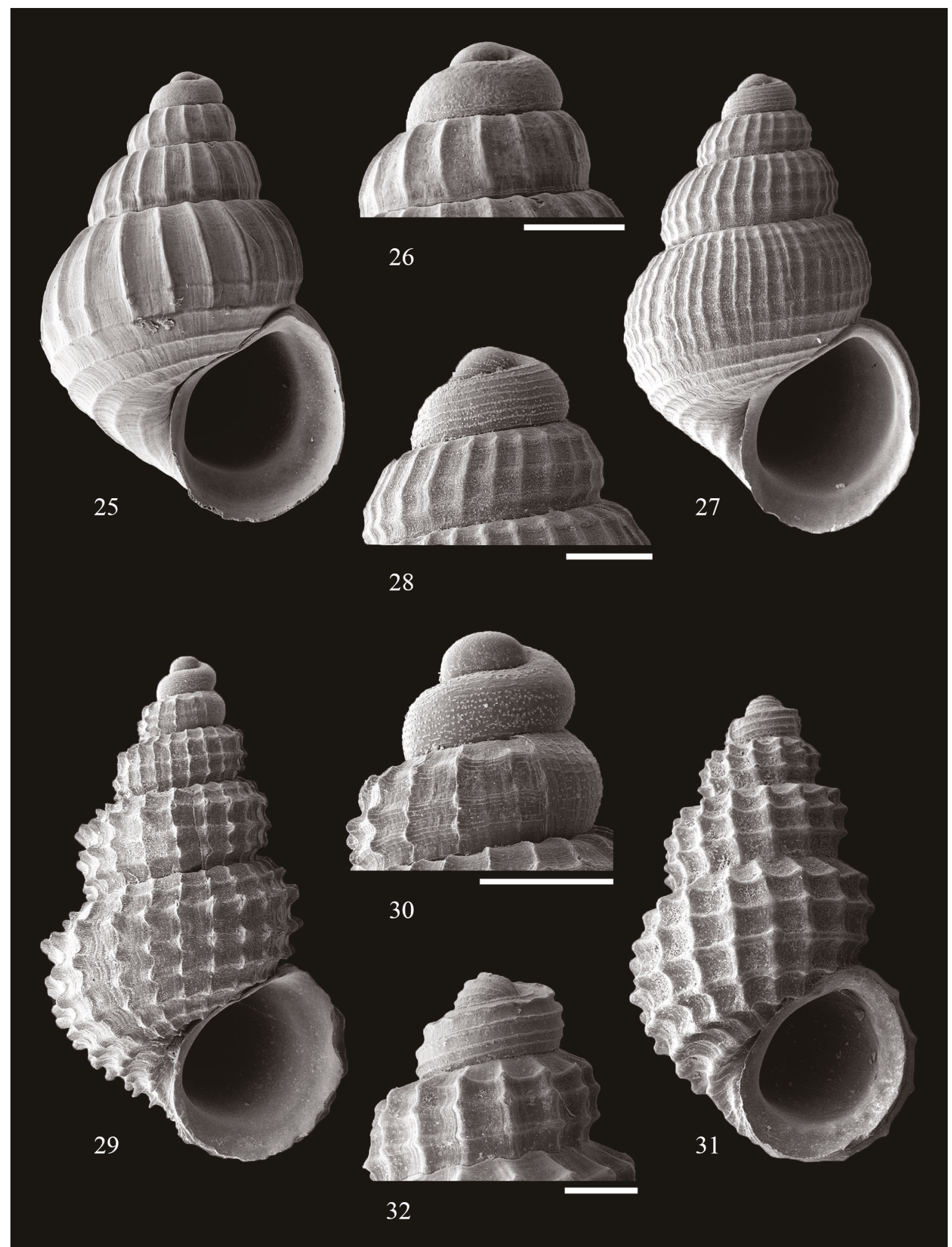

Figures 25, 26. Alvania adiaphoros, Great Meteor Seamount, M151-23425, H 1.9 mm, W 1.3 mm, Wp 0.30 mm. Figures 27, 28. Alvania adinogramma, Great Meteor Seamount, M151-23425, H 2.2 mm, W 1.4 mm, Wp 0.36 mm. Figures 29, 30. Alvania lamellata, Acor Bank, M151-23139, H 2.2 mm, W $1.3 \mathrm{~mm}, \mathrm{Wp} 0.39 \mathrm{~mm}$. Figures 31, 32. Alvania platycephala, Jose Gaspar Seamount, M151-23131, H $2.6 \mathrm{~mm}, \mathrm{~W} 1.5 \mathrm{~mm}$, Wp $43 \mathrm{~mm}$. Scale bars $0.2 \mathrm{~mm}$. 
1998). It was not found during M151 and its distribution seems to be restricted to the western Azorean Islands.

Alvania platycephala Dautzenberg et Fischer, 1896 is known from the central part of the Azores 274-952 m (Bouchet \& Warén, 1993). In our study, it was commonly found on the José Gaspar Seamount (M151-23105, 23131 - Figs. 31, 32 23161) and Mar da Prata off Sao Miguel (M151$23109,23111,23112,23114$ ) and on the Açor Bank off Fayal (M151-23139).

Alvania stenolopha Bouchet et Warén, 1993 is known from the Azores and the southern Azorean seamounts in 480-1600 m (Bouchet \& Warén, 1993; Gofas, 2007). In our study, it was found on the Albatroz Seamount (M151-23125; Figs. 33, 34), Great Meteor Seamount (M151-23425R9) and Little Meteor Seamount (M151-23437).

Alvania tarsodes (Watson, 1886) is common on the northern Azorean seamounts (Bouchet \& Warén, 1993, this study) in 293-1385 m. In our study, it was found on the José Gaspar Seamount (M151-23105, 23131 - Figs. 35, 36 - 23161) Mar da Prata off Sao Miguel (M151-23109, 23111, 23112, 23121), the Albatroz Seamount off Terceira (M151-23125) and the Açor Bank off Fayal (M151-23135, 23139).

Alvania zoderi Hoenselaar et Goud, 1998 was described from off Santa Maria in $620 \mathrm{~m}$ (Hoenselaar \& Goud, 1998). It was not found during M151; its distribution seems to be restricted near the type locality.

Amphirissoa cyclostomoides Dautzenberg et Fischer, 1897 is known from the central Azores and the southern Azorean seamounts in 280-1600 m (Bouchet \& Warén, 1993; Gofas, 2007). In our study, it was found on the José Gaspar Seamount (M151-23105, 23131 - Figs. 37, 38 - 23161).

Benthonella tenella (Jeffreys, 1869) is a common North Atlantic and Mediterranean deep-water species; it lives in 100-6000 m (Bouchet \& Warén, 1993; Gofas, 2007). It was found on Mar da Prata off Sao Miguel (M151-23121).

Benthonellania fayalensis (Watson, 1886) is known from the Azores and the Lusitanian Seamounts in 630-1300 m (Bouchet \& Warén, 1993; Gofas, 2007; Figs. 39, 40). In this study, it was not found on the Azorean Seamounts.

Porosalvania profundior Gofas, 2007 was originally reported from the Tyro-, Atlantis-, Irving-,
Cruiser- and Hyères Seamounts in 311-1190 m (Gofas, 2007). In this study it was found on the Atlantis (M151-23404), Great Meteor (M151-23419, 23425, 23427, 23429) and Little Meteor (M15123434, 23436, 23437, 23438) Seamounts. Near the Azores, it was found on the José Gaspar Seamount (M151-23161, Figs. 41, 42) and Mar da Prata (M151-23111, 23168) off Sao Miguel.

Pseudosetia azorica Bouchet et Warén, 1993 (Figs. 43, 44) is common on all Azorean seamounts in 337-834 m (Bouchet \& Warén, 1993; Gofas, 2007; this study). In our study, it was also found on the José Gaspar Seamount (M151-23105, 23131) and Mar da Prata off São Miguel (M15123109, 23111 - Figs. 43, 44 - 23112, 23114, 23162) and the Açor Bank off Fayal (M151-23135, 23139).

Pusillina fuscapex Gofas, 2007 was originally reported from the Atlantis-, Hyères- and Great Meteor Seamounts in 311-1190 m (Gofas, 2007). In this study it was found on the Atlantis (M15123404, 23408) and Great Meteor (M151-23419) Seamounts. Near the Azores, it was found on Mar da Prata (M151-23109, 23111, 23114; Figs. 4548) off São Miguel. The species can be identified by it smooth conical outline and its brown protoconch.

\section{Distribution of Azorean bathyal rissoids}

The distributions of the bathyal rissoids are summarized in Table 1. 36 species have been found deeper than $200 \mathrm{~m}$ on the southern and northern Azorean seamounts or on the slopes of the islands. Three bathyal species were also found in the sublittoral zone of Azorean islands: Crisilla quisquiliarum, Crisilla postrema and Obtusella intersecta. Two species originally reported from the southern seamounts (Gofas, 2007) have also been found on the northern seamounts (Porosalvania profundior and Pusillina fuscapex).

Seven bathyal rissoids or about $19 \%$ are solely known from a single seamount; $\mathrm{D}<30 \mathrm{~km}$. Three species are from the northern seamounts near the Azorean islands and four are from the southern seamounts. The newly described Alvania templadoi n. sp. and Crisilla herosae n. sp. were only found in the Mar da Prata area South of Sao Miguel.

24 bathyal species or about $67 \%$ are solely found either on the northern seamounts (11 species) 


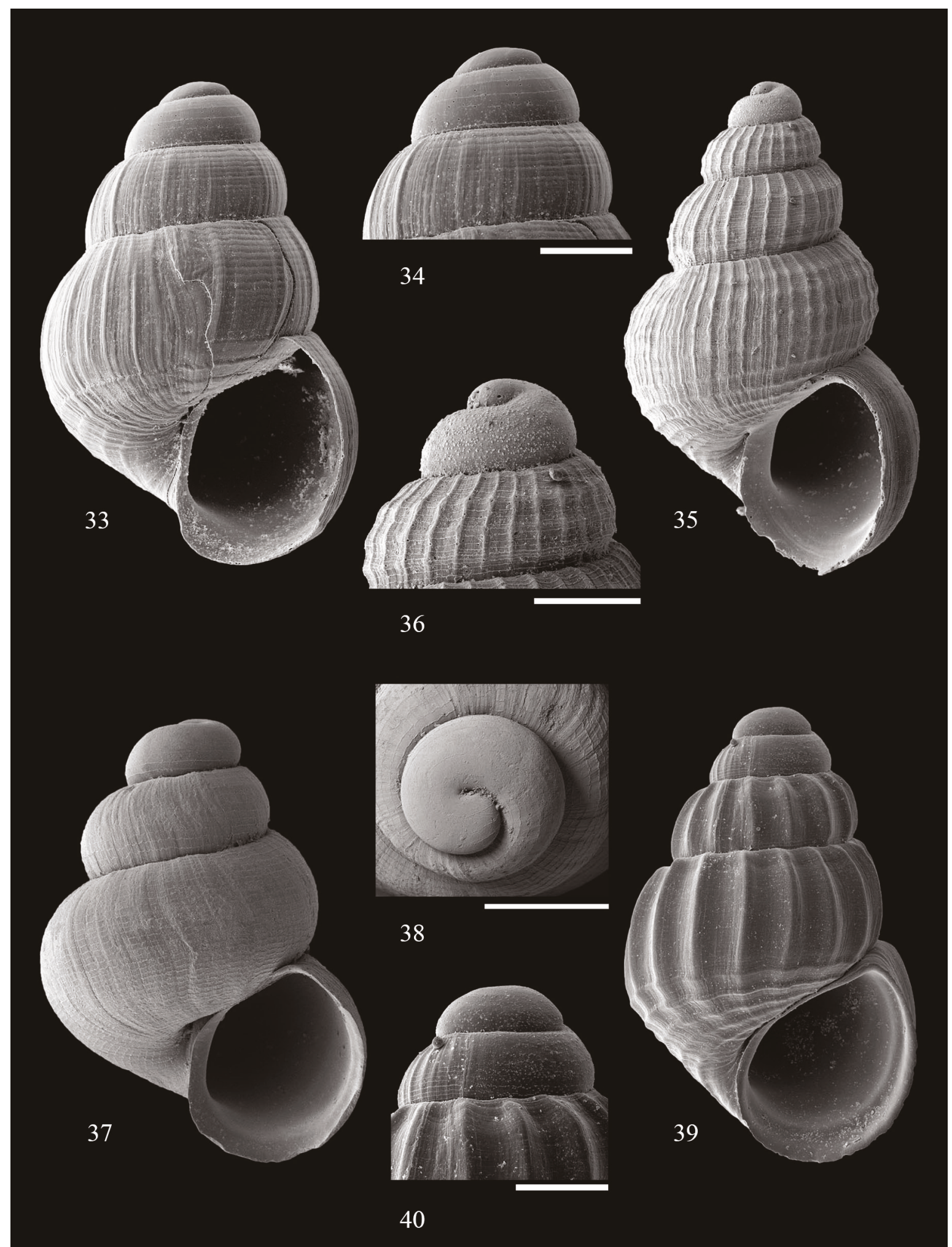

Figures 33, 34. Alvania stenalopha, Albatroz Seamount, M151-23125, H 1.3 mm, W 0.9 mm, Wp 0.38 mm. Figures 35 , 36. Alvania tarsodes, Jose Gaspar Seamount, M151-23131, H 1.9 mm, W $1.1 \mathrm{~mm}, \mathrm{Wp} 0.30 \mathrm{~mm}$. Figures 37, 38. Amphirissoa cyclostomoides, Jose Gaspar Seamount, M151-23131, H 1.0 mm, W 0.7 mm, Wp 29 mm. Figures 39, 40. Benthonellania fayalensis, Coral Patch Seamount, VH97-91, H $1.6 \mathrm{~mm}$, W $1.0 \mathrm{~mm}$, Wp $0.39 \mathrm{~mm}$. Scale bars $0.2 \mathrm{~mm}$. 


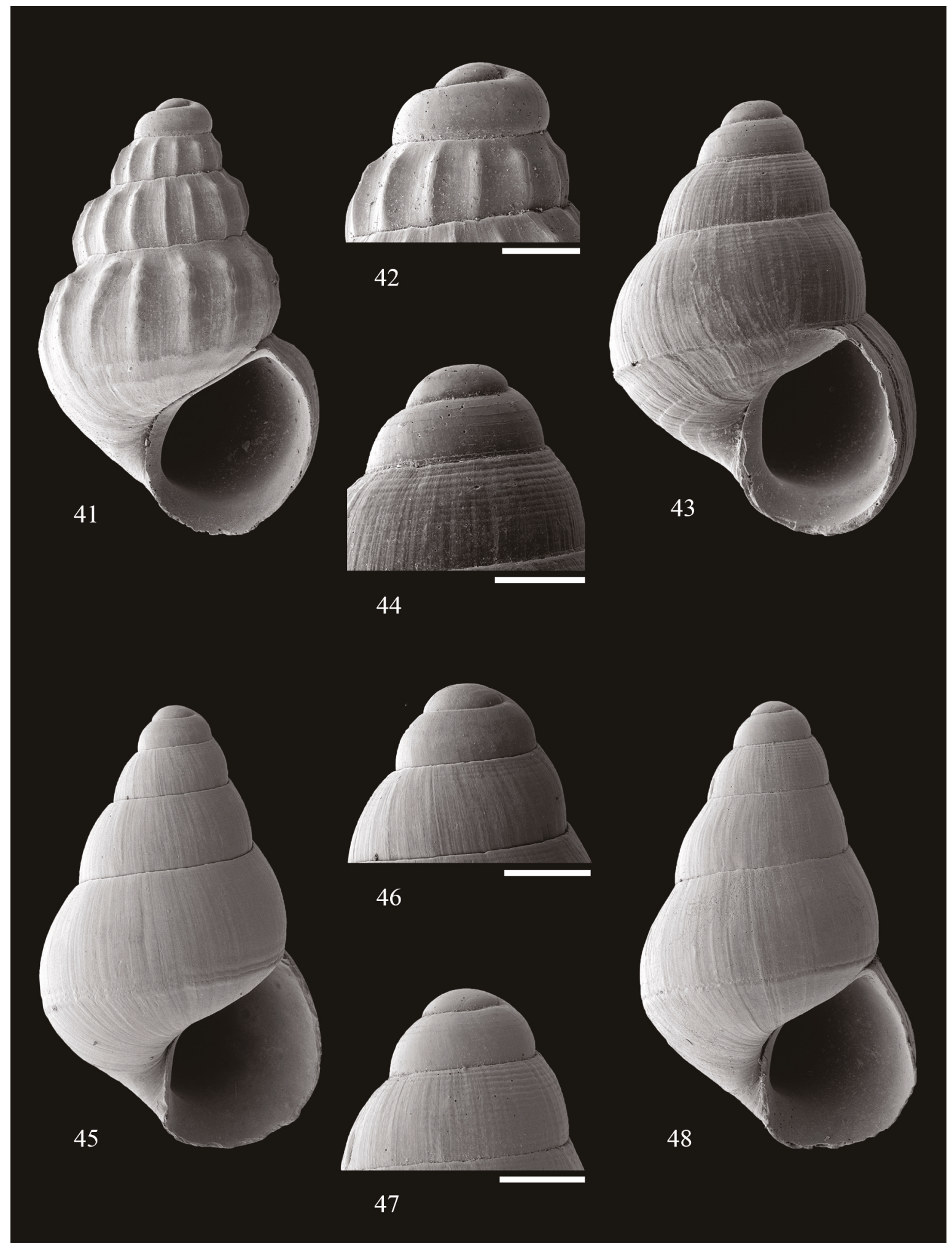

Figures 41, 42. Porosalvania profundior, Azores, Mar da Prata, M151-23161, H 2.3 mm, W 1.5 mm, Wp $0.41 \mathrm{~mm}$. Figures 43, 44. Pseudosetia azorica, Azores, Mar da Prata, M151-23111, H 1.6 mm, W 1.1 mm, Wp 0.40 mm. Figures 45-48. Pusillina fuscapex, Azores, Mar da Prata, M151-23114. Figs. 45, 46. Idem, H 2.0 mm, W 1.2 mm, Wp 0.33 mm. Fig. 47, 48. H $2.0 \mathrm{~mm}$, W $1.2 \mathrm{~mm}$, Wp $0.35 \mathrm{~mm}$. Scale bars $0.2 \mathrm{~mm}$. 


\begin{tabular}{|c|c|c|c|c|c|c|c|c|}
\hline Species & $\stackrel{\text { Lat-min }}{{ }^{\circ} \mathrm{N}}$ & $\stackrel{\text { Lat-max }}{{ }^{\circ} \mathbf{N}}$ & $\begin{array}{l}\text { Lon-min } \\
{ }^{\circ} \mathbf{W}\end{array}$ & $\begin{array}{c}\text { Lon- } \\
\max ^{\circ} \mathbf{W}\end{array}$ & $\begin{array}{c}\text { Depth } \\
\text { min (m) }\end{array}$ & $\begin{array}{c}\text { Depth } \\
\max (\mathrm{m})\end{array}$ & D (km) & Remark \\
\hline $\begin{array}{l}\text { Alvania adiaphoros } \\
\text { Bouchet et Warén, } 1993\end{array}$ & 29.6 & 39.4 & 25.1 & 31.4 & 274 & 952 & 1237 & $\begin{array}{l}\text { endemic to } \mathrm{N} \text { and } \mathrm{S} \\
\text { Azorean seamounts }\end{array}$ \\
\hline $\begin{array}{l}\text { Alvania adinogramma } \\
\text { Bouchet et Warén, } 1993\end{array}$ & 29.6 & 36.5 & 11.5 & 30.2 & 255 & 1050 & 1903 & $\begin{array}{l}\text { NE Atlantic; N Azo- } \\
\text { rean \& Lusitanian }\end{array}$ \\
\hline $\begin{array}{l}\text { Alvania cimicoides } \\
\text { (Forbes, 1844) }\end{array}$ & 19.9 & 67.0 & -15.6 & 29.1 & 90 & 1080 & 6346 & \begin{tabular}{|l|} 
NE Atlantic, \\
Mediterranean Sea \\
\end{tabular} \\
\hline $\begin{array}{l}\text { Alvania elenae } \\
\text { Gofas, } 2007\end{array}$ & 29.6 & 32.1 & 27.9 & 29.0 & 270 & 855 & 297 & $\begin{array}{l}\text { endemic to } \mathrm{S} \\
\text { Azorean seamounts }\end{array}$ \\
\hline $\begin{array}{l}\text { Alvania funiculata } \\
\text { Gofas, } 2007\end{array}$ & 29.6 & 34.4 & 27.5 & 30.5 & 464 & 1190 & 601 & \begin{tabular}{|l|} 
endemic to $\mathrm{S}$ \\
Azorean seamounts \\
\end{tabular} \\
\hline $\begin{array}{l}\text { Alvania lamellata } \\
\text { Dautzenberg, } 1889\end{array}$ & 37.7 & 38.6 & 25.7 & 29.1 & 293 & 1287 & 311 & \begin{tabular}{|l|} 
endemic to N \\
Azorean seamounts \\
\end{tabular} \\
\hline $\begin{array}{l}\text { Alvania macella } \\
\text { Gofas, } 2007\end{array}$ & 34.4 & 34.4 & 30.5 & 30.5 & 1190 & 1190 & 0 & $\begin{array}{l}\text { endemic to Atlantis } \\
\text { Seamount }\end{array}$ \\
\hline $\begin{array}{l}\text { Alvania micropilosa } \\
\text { Gofas, } 2007\end{array}$ & 29.6 & 32.1 & 27.9 & 29.0 & 274 & 852 & 291 & $\begin{array}{l}\text { endemic to } \mathrm{S} \\
\text { Azorean seamounts }\end{array}$ \\
\hline $\begin{array}{l}\text { Alvania microtuberculata } \\
\text { Gofas, } 2007\end{array}$ & 34.0 & 34.1 & 30.2 & 30.3 & 280 & 677 & 15 & $\begin{array}{l}\text { endemic to Atlantis } \\
\text { Seamount }\end{array}$ \\
\hline $\begin{array}{l}\text { Alvania nonsculpta } \\
\text { Hoenselaar et Goud, } 1998\end{array}$ & 38.5 & 39.4 & 28.6 & 31.1 & 165 & 200 & 240 & $\begin{array}{l}\text { endemic to } \mathrm{N} \\
\text { Azorean seamounts }\end{array}$ \\
\hline $\begin{array}{l}\text { Alvania platycephala } \\
\text { Dautzenberg et Fischer, } 1896\end{array}$ & 37.2 & 38.7 & 25.1 & 29.1 & 293 & 1385 & 384 & $\begin{array}{l}\text { endemic to } \mathrm{N} \\
\text { Azorean seamounts }\end{array}$ \\
\hline $\begin{array}{l}\text { Alvania stenolopha } \\
\text { Bouchet et Warén, } 1993\end{array}$ & 29.6 & 58.8 & 15.6 & 31.1 & 480 & 1600 & 3471 & NE Atlantic \\
\hline $\begin{array}{l}\text { Alvania suroiti } \\
\text { Gofas, } 2007\end{array}$ & 29.6 & 31.4 & 28.3 & 28.9 & 285 & 948 & 209 & \begin{tabular}{|l|} 
endemic to $\mathrm{S}$ \\
Azorean seamounts
\end{tabular} \\
\hline $\begin{array}{l}\text { Alvania tarsodes } \\
\text { (Watson, 1886) }\end{array}$ & 37.2 & 39.4 & 25.1 & 31.4 & 293 & 1385 & 600 & $\begin{array}{l}\text { endemic to } \mathrm{N} \\
\text { Azorean seamounts }\end{array}$ \\
\hline Alvania templadoi n. sp. & 37.7 & 37.7 & 25.9 & 25.9 & 406 & 834 & 2 & $\begin{array}{l}\text { endemic off São } \\
\text { Miguel }\end{array}$ \\
\hline $\begin{array}{l}\text { Alvania zoderi } \\
\text { Hoenselaar et Goud, } 1998\end{array}$ & 36.9 & 36.9 & 25.1 & 25.1 & 620 & 620 & 0 & $\begin{array}{l}\text { endemic off Santa } \\
\text { Maria }\end{array}$ \\
\hline $\begin{array}{l}\text { Amphirissoa cyclostomoides } \\
\text { Dautzenberg et Fischer, } 1897\end{array}$ & 32.3 & 39.2 & 25.7 & 30.5 & 280 & 1600 & 880 & $\begin{array}{l}\text { endemic to } \mathrm{N} \text { and } \mathrm{S} \\
\text { Azorean seamounts }\end{array}$ \\
\hline $\begin{array}{l}\text { Benthonella tenella } \\
\text { (Jeffreys, 1869) }\end{array}$ & 19.8 & 61.3 & -19.8 & 88.3 & 200 & 5500 & 10217 & N Atlantic \\
\hline $\begin{array}{l}\text { Benthonellania fayalensis } \\
\text { (Watson, 1886) }\end{array}$ & 35.0 & 38.6 & 12.0 & 28.5 & 630 & 1300 & 1525 & $\begin{array}{l}\text { NE Atlantic, N Azo- } \\
\text { rean \& Lusitanian }\end{array}$ \\
\hline $\begin{array}{l}\text { Crisilla postrema } \\
\text { (Gofas, 1990) }\end{array}$ & 37.7 & 39.4 & 25.7 & 31.1 & 0 & 339 & 510 & $\begin{array}{l}\text { endemic to } \mathrm{N} \\
\text { Azorean seamounts }\end{array}$ \\
\hline $\begin{array}{l}\text { Crisilla quisquiliarum } \\
\text { (Watson, 1886) }\end{array}$ & 38.2 & 38.6 & 27.2 & 29.1 & 0 & 730 & 169 & \begin{tabular}{|l|} 
endemic to N \\
Azorean seamounts
\end{tabular} \\
\hline Crisilla herosae n. sp. & 37.7 & 37.7 & 25.7 & 25.7 & 311 & 337 & 0 & $\begin{array}{l}\text { endemic off São } \\
\text { Miguel }\end{array}$ \\
\hline Crisilla avilai $\mathrm{n} . \mathrm{sp}$. & 37.7 & 38.4 & 25.9 & 29.1 & 406 & 834 & 286 & $\begin{array}{l}\text { endemic to } \mathrm{N} \\
\text { Azorean seamounts }\end{array}$ \\
\hline $\begin{array}{l}\text { Obtusella intersecta } \\
\text { (S.V. Wood, 1857) }\end{array}$ & -9.7 & 67.0 & -20.0 & 22.1 & 0 & 505 & 9463 & \begin{tabular}{|l} 
E Atlantic, \\
Mediterranean Sea
\end{tabular} \\
\hline $\begin{array}{l}\text { Obtusella roseotincta } \\
\text { (Dautzenberg, 1889) }\end{array}$ & 38.6 & 39.4 & 28.1 & 31.1 & 1287 & 1360 & 273 & $\begin{array}{l}\text { endemic to } \mathrm{N} \\
\text { Azorean seamounts }\end{array}$ \\
\hline $\begin{array}{l}\text { Porosalvania angulifera } \\
\text { Gofas, } 2007\end{array}$ & 29.7 & 31.5 & 28.4 & 29.0 & 285 & 1032 & 211 & $\begin{array}{l}\text { endemic to } \mathrm{S} \\
\text { Azorean seamounts }\end{array}$ \\
\hline $\begin{array}{l}\text { Porosalvania decipiens } \\
\text { Gofas, } 2007\end{array}$ & 31.2 & 31.3 & 28.6 & 28.7 & 845 & 1060 & 21 & $\begin{array}{l}\text { endemic to Hyères } \\
\text { Seamount }\end{array}$ \\
\hline $\begin{array}{l}\text { Porosalvania diaphana } \\
\text { Gofas, } 2007\end{array}$ & 33.2 & 33.2 & 28.9 & 28.9 & 690 & 690 & 0 & $\begin{array}{l}\text { endemic to Plato } \\
\text { Seamount }\end{array}$ \\
\hline
\end{tabular}




\begin{tabular}{|l|c|c|c|c|c|c|c|l|}
\hline $\begin{array}{l}\text { Porosalvania hydrobiaeformis } \\
\text { Gofas, 2007 }\end{array}$ & 31.2 & 34.4 & 28.4 & 30.5 & 677 & 1450 & 407 & $\begin{array}{l}\text { endemic to S } \\
\text { Azorean seamounts }\end{array}$ \\
\hline $\begin{array}{l}\text { Porosalvania profundior } \\
\text { Gofas, 2007 }\end{array}$ & 29.6 & 37.7 & 25.7 & 30.5 & 311 & 1190 & 1002 & $\begin{array}{l}\text { endemic to N and S } \\
\text { Azorean seamounts }\end{array}$ \\
\hline $\begin{array}{l}\text { Porosalvania semisculpta } \\
\text { Gofas, 2007 }\end{array}$ & 32.1 & 34.4 & 27.5 & 30.5 & 670 & 890 & 380 & $\begin{array}{l}\text { endemic to S } \\
\text { Azorean seamounts }\end{array}$ \\
\hline $\begin{array}{l}\text { Porosalvania solidula } \\
\text { Gofas, 2007 }\end{array}$ & 29.6 & 32.1 & 27.9 & 29.0 & 270 & 948 & 297 & $\begin{array}{l}\text { endemic to S } \\
\text { Azorean seamounts }\end{array}$ \\
\hline $\begin{array}{l}\text { Porosalvania vixplicata } \\
\text { Gofas, 2007 }\end{array}$ & 29.6 & 34.4 & 28.3 & 30.5 & 677 & 945 & 576 & $\begin{array}{l}\text { endemic to S } \\
\text { Azorean seamounts }\end{array}$ \\
\hline $\begin{array}{l}\text { Pseudosetia azorica } \\
\text { Bouchet et Warén, 1993 }\end{array}$ & 29.6 & 38.4 & 25.7 & 29.1 & 274 & 948 & 1025 & $\begin{array}{l}\text { endemic to N and S } \\
\text { Azorean seamounts }\end{array}$ \\
\hline $\begin{array}{l}\text { Pusillina fuscapex } \\
\text { Gofas, 2007 }\end{array}$ & 29.7 & 37.7 & 25.9 & 30.2 & 285 & 834 & 974 & $\begin{array}{l}\text { endemic to N and S } \\
\text { Azorean seamounts }\end{array}$ \\
\hline $\begin{array}{l}\text { Pusillina harpula } \\
\text { Gofas, 2007 }\end{array}$ & 31.3 & 36.5 & 11.5 & 30.5 & 255 & 1190 & 1838 & NE Atlantic \\
\hline
\end{tabular}

Table 1. Distribution of bathyal rissoids from the Azorean seamounts. Lat-min $=$ minimum latitude observed; Lat-max $=$ maximum latitude observed; Lon-min = minimum longitude observed; Lon-max = maximum longitude observed; $\mathrm{D}=\mathrm{di}$ stribution distance parameter.

or on the southern seamounts (13 species): $\mathrm{D}<800$ $\mathrm{km}$. The newly described Crisilla avilai $\mathrm{n}$. $\mathrm{sp}$. is endemic to the northern seamount area. Five additional species (about 14\%) are found over the full area of Azorean seamounts. Therefore, about $81 \%$ of the rissoids are endemic to the larger Azorean seamount area: $\mathrm{D}<1500 \mathrm{~km}$. The remaining seven species have a wider Atlantic distribution; only two species in this group have a planktonic larval development: Benthonella tenella and Alvania cimicoides.

The fractions of endemic species known from single seamounts (N: northern seamounts, 3 species, $8 \%$; S: southern seamounts, 4 species, $11 \%)$ or within a seamount group (N, 44\%; S, 50\%) are comparable between the southern and northern seamounts. Bathyal rissoids solely restricted to the northern area have a comparable degree of endemism (44\%) than shallow-water species (Ávila, 2000: 52\%). All endemic species have a non-planktonic larval development.

Obviously, the actual sampling density in the large sea-bottom area is low and strongly inhomogeneous. It can be expected that infill sampling of poorly covered bathyal areas and biotopes will yield more species with a very limited distribution range and it will increase the range of currently-known species. Nevertheless, the larvae of a significant fraction of species seem unable to cross the deep bathyal or abyssal gaps of some $30-100 \mathrm{~km}$ between seamounts. A number of species can bridge these gaps and are able to distribute over a larger seamount area but are stopped by the relatively large gap of about $200 \mathrm{~km}$ between the southern and northern seamounts. About $20 \%$ the rissoid taxa from the Azorean seamounts are also found near Madeira, the Lusitanian seamounts or the Rockall and Hatton banks; this distribution requires larvae that cross a distance of 1500-2000 km and abyssal depths exceeding $3000 \mathrm{~m}$.

\section{Paleontological considerations}

Lozouet et al. (2001) discussed various species in the genus Alvania and one in Pusillina from the lower Miocene (Aquitanian, 20-23 Ma). Landau et al. (2018) described a large rissoid diversity in the Upper Miocene (Tortonian, 12-7 Ma). Nearly all Recent rissoid genera are represented in his Tortonian malaco-community; the majority of species are identified in the genus Alvania and the larval development of most rissoids seems non-planktonic. Van Dingenen et al (2016) showed a large rissoid fauna in Lower Pliocene (Zanclean, 5.3-3.6 Ma) outcrop from western France; even though the great majority of species are extinct, the generic composition is similar to that of the living Recent Rissoidae. European genera like Alvania, Pseudosetia, Pusillina, Onoba, Rissoa, Manzonia and Setia are well represented in the Neogene fauna and these genera are currently represented by many endemic species on the Azorean seamounts. For 
example, Alvania cimicoides, Alvania tarsodes and Alvania sleursi have been living around the Azores since the Pleistocene (Ávila et al., 2009). The genera Porosalvania and Gofasia seem to be absent in north-western European fauna during the Neogene era at the time when the Azorean seamounts were formed and populated.

It is likely that the majority of the bathyal Rissoidae evolved from the initial NE Atlantic populations after formation of the seamounts between the Middle Miocene and Pliocene. A minority of the Recent Azorean rissoid fauna reached the seamounts from the continental, Lusitanian, Madeiran, Canarian, and Rockall-Hatton areas possibly by planktonic rafting with an enhanced connectivity facilitated by intermediate islands and seamounts.

\section{ACKNOWLEDGEMENTS}

Crew and scientific staff of cruise M151 (R/V Meteor) are thanked for their dedication in collecting the samples used in this study. Nicol Mahnken assisted in the preparation of the SEM images. Cruise M151 was funded by the Deutsche Forschungsgemeinschaft.

\section{REFERENCES}

Ávila S.P., 2000. Shallow-water marine molluscs of the Azores: biogeographical relationships. Life and Marine Sciences, Supplement, 2(A): 99-131.

Ávila S.P., Silva C., Schiebel R., Cecca F., Backeljau T. \& De Frias Martins A.M., 2009. How did they get here? The biogeography of the marine molluscs of the Azores. Bulletin de la Societe Geologique de France, 180: 295-307. https://doi.org/10.2113/gssgfbull.180.4.295

Ávila S.P., Goud J. \& De Frias Martins A.M., 2012. Patterns of diversity of the Rissoidae (Mollusca: Gastropoda) in the Atlantic and the Mediterranean Region. The Scientific World Journal (Article ID 164890): 1-30. https://doi.org/10.1100/2012/164890

Bouchet P. \& Warén A., 1993. Revision of the Northeast Atlantic bathyal and abyssal Mesogastropoda. Bollettino Malacologico, supplemento 3: 579-840.

Coates A.G. \& Obando J.A., 1996. The geologic evolution of the Central American Isthmus. In: Jackson J.B.C., Budd A.F. \& Coates A.G. (Eds.), Evolution and Environment in Tropical America, pp. 21-56. University of Chicago, Chicago.

Cordeiro R. \& Ávila S.P., 2015. New species of Rissoidae (Mollusca, Gastropoda) from the Archipelago of the Azores (northeast Atlantic) with an updated regional checklist for the family. ZooKeys, 480: 1-19. https://doi.org/10.3897/zookeys.480.8599

De Frias Martins A.M., Borges J., Ávila S.P., Costa A., Madeira P., \& Morton B., 2009. Illustrated checklist of the infralittoral molluscs off Vila Franca do Campo. Açoreana, 6: 15-103.

Driscoll N.W. \& Haug G.H., 1998. A short circuit in thermohaline circulation: A cause for northern hemisphere glaciation? Science, 282(5388): 436-438. https://doi.org/10.1126/science.282.5388.436

Frank N., 2018. Short Cruise Report. M151. Atlantic Thermocline Ocean and Ecosystems Dynamic during Natural Climate Change. Ponta Delgada - Funchal, Portugal. 6-31 October 2018. 15 pp. (not published) Institut für Umweltphysik, Universität Heidelberg, Heidelberg, Germany

Gofas S., 1990. The littoral Rissoidae and Anabathridae of Sao Miguel, Azores. In: Proceedings $1^{\text {st }}$ international workshop on malacology, Sao Miguel, july 1988. Açoreana, Ponta Delgada suplemento: 97-134.

Gofas S., 2007. Rissoidae (Mollusca: Gastropoda) from northeast Atlantic seamounts. Journal of Natural History, 41: 779-885. http://dx.doi.org/10.1080/00222930701298085

Haug G.H. \& Tiedemann R., 1998. Effect of the formation of the Isthmus of Panama on Atlantic Ocean thermohaline circulation. Nature. 393: 673-676. http://dx.doi.org/10.1038/31447.

Hoenselaar H.J. \& Goud J., 1998. The Rissoidae of the CANCAP expeditions, I: the genus Alvania Risso, 1826 (Gastropoda, Prosobranchia). Basteria, 62: 69115.

Hoffman L. \& Freiwald A., 2020. Bathyal Eulimidae (Gastropoda: Vanikoroidea) from the Azorean seamounts collected during the Cruise M151 with the description of three new species. Miscellanea Malacologica, 8: 81-99.

Landau B.M., Ceulemans L. \& Van Dingenen F., 2018. The upper Miocene gastropods of northwestern France, 2. Caenogastropoda. Cainozoic Research, 18: 177-368.

Lozouet P., Lesport J.F. \& Renard P., 2001. Révision des Gastropoda (Mollusca) du stratotype de L'Aquitanien (Miocène Inf.): site de Saucats "Lariey", Gironde, France. Cossmanniana. hors-série 3: 1-189.

Madeira J., 1986. Geologia estrutural e enquadramento geotectónico da ilha de Santa Maria (Açores). MSc. Thesis, Lisboa, 107 pp.

Sepkoski J.J. Jr., 2002. A compendium of fossil marine animal genera. Bulletins of American Paleontology, 363: $1-560$. 
Serralheiro A., 2003. A geologia da ilha de Santa Maria, Açores. Açoreana, 10: 141-192.

Serralheiro A. \& Madeira J., 1990. Stratigraphy and geochronology of Santa Maria Island (Azores). Açoreana, 7: 575-592.

Van Dingenen F., Ceulemans L. \& Landau B.M., 2016.
The lower Pliocene gastropods of Le Pigeon Blanc (Loire-Atlantique, north west France), 2. Caenogastropoda. Cainozoic Research, 16: 109-219.

WoRMS Editorial Board, 2020. World Register of Marine Species. Available from http://www.marinespecies.org at VLIZ. Accessed 2020-10-01. 